\title{
HYPNOTIC ASSESSMENT AND TREATMENT OF TRAUMA-INDUCED PSYCHOSES: The Early Psychotherapy of $\mathrm{H}$. Breukink and Modern Views
}

\author{
Onno van der Hart \\ Utrecht University, The Netherlands \\ David Spiegel \\ Stanford University School of Medicine
}

\begin{abstract}
The role of hypnotizability assessment in the differential diagn0sis of psychotic patients is still unresolved. In this article, the pioneering work of Dutch psychiatrist H. Breukink (1860-1928) during the 1920s is used as early evidence that hypnotic capacity is clinically helpful in differentiating highly hypnotizable psychotic patients with dissociative symptomatology from schizophrenics. Furthermore, there is a long tradition of employing hypnotic capacity in the treatment of these dissociative psychoses. The ways in which Breukink used hypnosis for diagnostic, prognostic, and treatment purposes are summarized and discussed in light of both old and current views. He felt that hysterical psychosis was trauma-induced, certainly curable, and that psychotherapy using hypnosis was the treatment of choice. Hypnosis was used for symptom-oriented therapy, as a comfortable and supportive mental state, and for the uncovering and integrating of traumatic memories. For the latter purpose, Breukink emphasized a calm mental state, both in hypnosis and in the waking state, thereby discouraging emotional expression, which he considered dangerous in psychotic patients. In the discussion, special attention is paid to the role and dangers of the expression of trauma-related emotions.
\end{abstract}

There is a substantial literature demonstrating that psychotic patients, especially these with schizophrenia, perform differently on hypnotizability scales than do normal individuals. In particular, their scores are substantially lower than normal control samples on the Hypnotic Induction Profile (Pettinati, 1982, Pettinati et al., 1990; Spiegel, Detrick, \& Frischholz, 1982). Mean scores of schizophrenics have not been found to be lower than normal in studies (Lavoie \& Elie, 1985; Lavoie \& Sabourin, 1980; Pettinati, 1982) employing the Stanford
Hypnotic Susceptibility Scales (Weitzenhoffer \& Hilgard, 1959, 1962). However, these studies show lower variance in scores, resulting in the relative absence of very high hypnotizability among these samples. Furthermore, Lavoie and Elie (1985) found significantly fewer autistic forms of primary process on the Rorschachs of more as compared with less hypnotizable schizophrenics. Thus, in their studies with the Stanford scales, despite the absence of differences in mean scores of normals and schizophrenics, the less hypnotizable schizophrenic patients were 
more impaired, and very few of them were highly hypnotizable.

Thus schizophrenic patients would be expected to be relatively immune to the benefits of treatment employing hypnosis. Nonetheless, there are psychotic patients who are hypnotizable and therefore may benefit from psychotherapy using hypnosis (see Lavoie \& Elie, 1985; Lavoie \& Sabourin, 1980; MurrayJobsis, 1991). At least one subtype of these hypnotizable psychotic patients is considered to be in a state of uncontrolled self-hypnosis and suffering from dissociative symptomatology (Spiegel \& Fink, 1979; Steingard \& Frankel, 1985). These patients have traditionally been diagnosed as having hysterical psychosis (see Hirsch \& Hollender, 1964), a diagnostic category not currently used. The closest current diagnostic category is atypical psychosis, according to the DSM-III-R (American Psychiatric Association, 1987). Emphasizing that this type of psychosis is usually trauma-induced, van der Hart, Witztum, and Friedman (1993) propose to call it reactive dissociative psychosis instead.

This literature provides evidence that the assessment of hypnotizability has value in the differential diagnosis between schizophrenia and hysterical, atypical, or reactive dissociative psychosis, regardless of the existing controversy about the hypnotizability of schizophrenics. Second, hypnosis can be used productively in psychotherapy with patients with hysterical or reactive dissociative psychosis. Given the putative role of trauma in inducing such psychotic illness, special emphasis is given to the use of hypnotic techniques in the treatment of these patients' traumatic memories.

We take as a point of departure the important but little-known work of the Dutch master of hypnosis, H. Breukink (1860-1928). His views on hypnosis in the differential diagnosis of psychotic patients and his clinical applications of hypnosis in the treatment of certain psychoses continue to make an important contribution to current clinical thinking. Breukink's research was published in the Nederlands Tijdschrift voor Geneeskunde [Dutch Journal of Medicine] (Breukink, 1923a 1923b, 1924, 1925a, 1925b, 1925c, 1926). In the English hypnosis literature, they have been referred to by Viëtor (1964).

\section{BREUKINK'S APPLICATION OF HYPNOSIS WITH PSYCHOTIC PATIENTS}

Breukink was a psychiatrist and a fameus hypnotherapist at the Geneeskundig Gesticht voor Krankzinnigen [Psychiatric Institute] in Utrecht, the Netherlands. He had his own ward for psychotherapy patients, and in this ward there was a special unit for patients who were treated with hypnosis (Breukink, 1923a, 1923b, 1924). He was a most successful hypnotherapist, not only of psychotic patients but of neurotics as wel1. Recognizing his talents, the Raad van Arbeid [Labor Council] in Utrecht sent many chronic as well as acute patients to him for hypnotic treatment. That this treatment was usually effective was recognized after his death in 1928, in a highly appreciative article in the Geneeskundig Tijdschrift der Rijks verzekeringsbank [Medical Journal of the State Insurance Bank] (Gravestein, 1928). Reading Breukink's case reports, the modern reader gets the impression that his high success rate was due not only to his employment of specific hypnotic techniques, often in combination with many other approaches, but also to his strong belief in the patient's ability to recover once his or her hypnotizability was established (see Frank, 1973).

As Breukink's writings are rather sketchy, in this review, care is taken to elucidate some of his views. These as well as Breukink's hypnotic techniques are compared with these of his predecessors and contemporaries and with those of modern researchers and clinicians.

The patient's hypnotizability played a major role in Breukink's diagnostic system, prognostic considerations, and treatment strategies. He did not use formal hypnotizability scales but believed he was able to assess patient's hypnotic capacity via a clinical impression of their responsiveness to the use of simple induction techniques.

Breukink summarized his ample clinical experiences with the use of hypnosis in psychotic inpatients with the following propositions.

1. Hypnosis can be an important differential-diagnostic instrument in the 
assessment of the psychoses. He stated that psychotic patients are often mistakenly diagnosed as suffering from dementia praecox (schizophrenia). Psychotic patients who are highly hypnotizable, he felt, are really suffering from hysterical psychoses (see Copeland \& Kitching, 1937; Mallett \& Gold, 1964; Spiegel \& Fink, 1979; van der Hart et a1., 1993). Breukink observed that hysterical psychosis and agitated farms of schizophrenia are of ten confused, with grave implications for treatment. Breukink also found that patients with a so-called degenerative (or borderline) psychosis were also more hypnotizable than schizophrenics.

2. When a psychotic patient can be hypnotized, the patient can be cured. Breukink took an absolute position in this regard: "It has been proved to me so far without exception that when a [psychotic] patient CID enter a light grade of hypnosis, then the curability of the psychosis has also been established" (Breukink, 1923b, p. 924). This viewpoint antedated but was consistent with those in the English literature (Copeland \& Kitching, 1937). He observed that one can hypnotize such patients even when they are in a state of strong affective arousal.

Breukink found hypnosis to be useless in the treatment of common melancholia. He concluded that patients with true psychotic melancholia were not hypnotizable but could still be treated successfully by other means. In melancholia with a neurotic component, hypnosis could be useful as a sedative, but despite a good night's sleep, the patient would usually wake up the next morning with the same melancholia. In cases of hysterical melancholia, Breukink was often able to induce improvement using hypnosis and hypnocatharsis.

3. A combination of hypnotic and other treatment techniques is most effective. Breukink's treatment goal was to restore the patient's relationship with reality. He found a combination of hypnotic and nonhypnotic techniques to be most effective. He used the following hypnotic techniques: (a) direct symptom-oriented suggestions (e.g., for relaxation, sound sleep, ego-strengthening, and increased will power); (b) prolonged sleep like deep hypnosis, which, like Janet (1898/1983a) and Wetterstrand (1982), he found beneficial in a general sense; and (c) hypnotic techniques for the exploration, modification, and integration of underlying traumatic memories or complexes. He called these techniques his "cathartic hypnotic method."

Among Breukink's nonhypnotic techniques, he recommended encouraging and guiding patients to work and orient themselves outside the clinic (Breukink, 1924). He considered this a kind of re-education that taught patients to adapt to society.

Breukink believed that his treatment with hypnosis and "catharsis" produced such good results "because more or less deep hypnosis works soothingly, the catharsis liberates patients from their complexes, and the doctor, with his suggestions which should always be constructive and convincing, gives self-confidence and will power back to them" (Breukink, 1925a, p. 1880).

4. A special form of cathartic-hypnotic method is advisable in the treatment of psychotic patients. Breukink found traumatic and other stressful life events to be a major etiological factor in hysterical and related psychoses. His exploratory techniques seemed to consist of directing the patient under hypnosis to the traumatic memories underlying the patient's psychosis and allowing the patient to relate what had happened in a calm state of mind associated with physical relaxation. The traumatic events were discussed with the patient in this calm state of mind, and finally Breukink would suggest that the patient could remember everything upon returning to the waking state. Thus Breukink used the word "catharsis" mainly in the sense of cognitive revivification, not in the sense of an emotional abreaction.

In addition to these guiding principles, Breukink followed the same phase-oriented model that can be found in the work of Janet (see van der Hart, Brown, \& van der Kolk, 1989). It consists of the following stages: stabilization and symptom reduction, modification of traumatic memories, and personality reintegration and rehabilitation. 


\section{CASE EXAMPLES}

\section{CASE 1}

Ms. X, a young, unmarried woman, hospitalized two years for manic-depressive psychosis, was referred to Breukink in March 1923 by a colleague in the same hospital for hypnotherapy as a last resort (Breukink, 1924). She had previously been hospitalized five times elsewhere. Upon admission, in March 1921, Breukink had noted a hysterical foundation to her illness. As she had been unresponsive to simple hypnotic suggestions, he had not pursued hypnosis further at the time.

During her 1921-1923 hospitalization, visual hallucinations, religious delusions, and a trancelike mental state were noted in Ms. X. She was frequently verbally abusive and. physically aggressive toward other patients, nurses, and the attending psychiatrist. During that two-year stay, she had been put into restraints for 1,192 hours. Medication (BromineNatrium and Venoral) had been of no help. In her trancelike state, manifestations of traumatic grief regarding her mother's death same two years before the last admission became apparent. As her mental state had deteriorated during the two years of this hospitalization, hypnosis was again attempted as a last resort on March 6, 1923, while she was in a highly disturbed condition. Twice that day, Breukink succeeded in inducing a sleep-like state. When she awoke she reported she had slept wonderfully and felt rested. The next day, however, she was again severely disturbed and had to be immobilized again. The same evening Breukink hypnotized her and suggested prolonged sleep and let her sleep for a couple of days, with moments in between for eating and personal hygiene.

On March 14, 1923, Breukink started his exploratory hypnotic approach. During this and subsequent sessions, the patient reported both in the hypnotic state and in the waking state details of a disturbed home situation with an alcoholic father who had been abusive toward her mother and herself. Her brothers and sisters were married and had left the house. They would return for a visit when the father was not at home. Her father had called the patient the lover of her mother. He had a gun, and his threats to kill her and her mother had greatly upset her. In hypnosis she related that when her mother was in the hospital for a year, her father had sexually assaulted her a number of times -something she had never spoken about before. When the mother returned home, it soon became apparent that she was terminally ill. Ms. X worked during the day; during the evenings and nights she took care of her mother. One evening, the mother told her to put flowers near her bed and to give her a bouquet after her death. A few days later, she died. Ms. X was unable to accept this and to take the necessary actions. She slept beside the corpse for two nights.

Breukink was scan able to revise his view of the patient's prognosis. On March 28, she had already improved greatly, and she was transferred to the psychotherapy unit on the hypnosis ward. Breukink urged her to work in the hospital and soon let her walk with a nurse or another patient outside the hospital "for treatment, because I believe that these patients must learn to restore their relationship with society and must learn to take their own responsibility" (Breukink, 1924, p. 916).

Breukink did not provide further follow-up information. It thus remains unknown if earlier traumatization -which modern readers familiar with the psychological sequelae of incest would expect- had also come to light.

\section{CASE 2}

A 32-year-old woman came under Breukink's care in January 1924. He diagnosed her condition as hysterical psychosis (Breukink, 1925a). In previous years she had been suffering from "nerves" and could no longer carry out her job as a saleswoman. Her desire was to be a maidservant for the nurses. Rest cures and the like had not helped her. She deteriorated physically and spent most of her time at home depressed and without work. She became more disturbed, had a number of hysterical attacks, entered a dream-like state in which she saw the devil, and engaged in a variety of religious sermons, which led to her being admitted to a mental institution. In the hospital, she was initially highly agitated, talking continuously about the devil and saying she had to convert everyone. She suffered a number of such attacks. 
With the use of hypnosis, this patient, too, could quickly go into a quiet sleep. Therefore, she was managed from the beginning at the psychotherapeutic unit.

During hypnotic catharsis, conflicts of a sexual nature (masturbation since age 7, homosexual relationship with a teacher) were brought to light. She improved with continuous treatment, becoming more calm and cheerful. After 3 weeks she helped with household chores, was allowed to walk outside, and was, despite same milder attacks, probationarily discharged a month later.

Attempts to find suitable work for her unfortunately did not succeed. However, at the time that Breukink wrote this report the patient was rather active with her housework and made a small outside income by selling handmade articles.

\section{DISCUSSION}

The experience of this prominent early 20thcentury Dutch psychiatrist illustrates a number of themes that are germane to current thinking about hypnosis and psychosis.

1. The assessment of hypnotic capacity is important to differential diagnosis. Following Pierre Janet ("Elles ne sont pas des aliénées comme les autres," quoted in Breukink, 1924, p. 918), Breukink (1924) considered psychotic patients who were hypnotizable to be different from these who could not be hypnotized. In particular, he viewed these hypnotizable psychotic patients as not being schizophrenic, as having a far more favourable prognosis, and as being treatable with psychotherapeutic methods. Similarly, Copeland and Kitching (1937) reported that "without exception cases which presented a true psychosis could not be hypnotized. If susceptibility to hypnosis developed, we were compelled to revise the diagnosis" (p. 328).

Although such absolute positions may be correctly criticized in that they reduce parametric to nonparametric data, in particular to nominal and mutually exclusive categories, they can serve as a point of departure for a discussion of an important clinical and research area. The emphasis these old masters placed on hypnosis as a diagnostic and prognostic tool was a forerunner of the modern use of hypnotizability assessment of psychotic patients in both laboratory and clinical settings (Hilgard, 1965; Lavoie \& Sabourin, 1980; Murray-Jobsis, 1991; Pettinati, 1982; Spiegel et aL, 1982; Spiegel \& Spiegel, 1978/1987). In particular, Breukink's concIusion that high hypnotizability in psychotic patients is a good prognostic sign has been supported by modern research (see Lavoie \& Elie, 1985; Lavoie, Michaud, Elie, \& Amar, 1987; Michaud, Lavoie, Elie, \& Amar, 1987) as weU as clinical studies (see Lavoie \& Sabourin, 1980; Murray-Jobsis, 1991; Scagnelli, 1976; Scagnelli-Jobsis, 1982; Spiegel \& Fink, 1979). It should be noted, however, that a great number of important follow-up studies in the field of schizophrenia indicate that there is a wide range of outcome in schizophrenia (M. Bleuler, 1978, 1983; Carpenter, Bartko, Strauss, \& Hawk, 1978; Carpenter \& Strauss, 1977; Ciompi, 1978; Harding \& Brooks, 1984; Harding, Brooks, Ashikaga, Strauss, \& Breier, 1987; Huber \& Gross, 1980). Although these studies did not address the factor of hypnotizability, they leave ample room for hypnotizability as one prognostic factor accounting for "variance in outcome.

There is less agreement about the relationship between hypnotizability and diagnosis, as opposed to prognosis. One relevant issue is a definition of schizophrenia as a more or less all-encompassing diagnostic category. Breukink held a rather clear view that schizophrenia was inconsistent with the ability to experience hypnosis. This is consistent with current research indicating that disciplined and reversible changes in the mental state typical of hypnosis (D. Spiegel, 1988) are by and large beyond the capabilities of patients with schizophrenia (Spiegel et a1., 1982). This allows us to distinguish between patients with primary schizophrenia and these with a reactive, atypical, or hysterical psychosis (Hirsch \& Hollender, 1964; Mallet \& Gold, 1964; Spiegel \& Fink, 1979; see van der Hart et a1., 1993, for a review of the history of hysterical psychosis). Breukink's position that psychotherapy using hypnosis is the treatment of choice for this subset of psychotic patients reflects cider psychiatric views (see Janet, 1894-1895/1990, 
1898/1983a; Moreau de Tours, 1869) as well as same later views (Copeland \& Kitching, 1937; Spiegel \& Fink, 1979; Steingard \& Frankel, 1985; van der Hart et a1., 1993; Witztum, Buchbinder, \& van der Hart, 1990). Indeed, the identification of this subset of psychotic patients provides an opportunity for the use of hypnosis in initially tapping and identifying symptoms in a spontaneous dissociative state, which provides the grounds tor controlling these symptoms. This treatment approach builds uren Puységur's (Puységur, 1816; see also Lavoie \& Sabourin, 1980), Janet's (1898/1983a), and Breuer's (Breuer \& Freud, 1895/1955) original observations that dissociative symptoms may be related to uncontrolled somnambulistic or hypnotic states. Inducing them with the formal use of hypnosis is the first step toward gaining control of them. As illustrated in the work of Breukink and further discussed below, subsequent steps may be directed toward the resolution and integration of traumatic memories that of ten both stimulate and are defended against by these dissociative states.

Following the influential work of E. Bleuler (1911, 1950), who spoke of "the group of schizophrenias," the second position views schizophrenia as covering a rather wide range of phenomena. Studies based on this position differentiate between schizophrenia and other psychoses. Like E. Bleuler, they do not, however, address the specific issues of hysterical psychosis and multiple personality disorder (MPD). Thus studies on hypnotizability in psychotic patients based on this position conclude that schizophrenic patients, diagnosed as such with the best available criteria of schizophrenia, may exhibit a wide range of hypnotizability, just as they may widely differ in many other areas of functioning. In other words, hypnotizability is not regarded as a valid enough criterion to rule out a diagnosis of schizophrenia.

Same of the variation in the measured hypnotizability of psychotic patients can be accounted for by misdiagnosis. As H. Spiegel (1991) commented, reviewing a study by Murray-Jobsis (1991) on the hypnotic capacity of schizophrenics and borderline patients in a clinical setting, "Without a careful differential diagnosis, hysterical psychosis and multiple personality disorder are often diagnosed as schizophrenia. Positive transference with compliance to the therapist's expectations can generate the demand characteristics that are most likely with hysteria and least likely with schizophrenics or borderlines" (p. 164). Indeed, as long as these diagnostic categories are more or less ignored by the average clinician, they will be subsumed under other dominant categories, including schizophrenia. Although hysterical psychosis is still a largely ignored diagnostic category, there exists ample evidence that this is a frequent error with regard to MPD, a more widely recognized diagnosis. According to Kluft (1987) and Loewenstein (1991), this severe dissociative disorder has first-rank Schneiderian symptoms in common with schizophrenia (i.e., passive influence symptoms and interference phenomena). Several large-scale studies show that a high proportion (up to $40 \%$ ) of MPD patients have previously been diagnosed as having schizophrenia (Boon \& Draijer, in press; Putnam, Guroff Silberman, Barban, \& Post, 1986; Ross, Norton, \& Wozney, 1989). Recent developments with regard to structured clinical interviews for the dissociative disorders, such as the SCID-D (Steinberg, Rounsaville, \& Cicchetti, 1990) and the DDIS (Ross, 1989) are extremely helpful in preventing a false diagnosis of schizophrenia in cases of MPD and other dissociative disorders. Fink and Golinkoff (1990) found that MPD patients had mean Dissociative Experiences Scale (DES; Bernstein \& Putnam, 1986) scores that were four times as high as those obtained by schizophrenics. They were also far more likely to have suffered physical and sexual abuse.

With regard to hysterical psychosis, such diagnostic tools are not as well established. Lavoie and Elie (1985) call for "controlled studies of the relationship between the dissociative processes in psychosis and in the hypnotic experience," which are "virtually absent" (p. 59). Van der Hart et al. (1993) quote Janet (1894-1895/1990), who said that for a psychosis to be hysterical, its dissociative nature should be established, as identified by the following criteria: (a) The psychosis is embedded in dissociative phenomena; (b) the psychosis itself can be seen as a dissociated 
state; (c) a splitting or doubling of the mind (dédoublement de la personnalité) has occurred; (d) subconscious phenomena are observed; and (e) altered states of consciousness occur. In recent times, a number of instruments, such as the Dissociative Questionnaire (DIS-Q; Vanderlinden, van Dyck, Vandereycken, \& Vertommen, 1991), have been developed for the measurement of dissociation. MPD patients constitute the diagnostic group with the highest scores on such scales (see Bernstein \& Putnam, 1986). Psychotic patients who score high on such scales are probably suffering from hysterical psychosis. Incidentally, Janet $(1889 / 1973)$ also believed that high hypnotizability is rooted in dissociation. Dissociation bas been characterized as one of the three components of the hypnotic experience the others being absorption and suggestibility (D. Spiegel 1990). In addition, based on a review of the relevant literature, van der Hart et al. (1993) conclude that hysterical psychosis is usually trauma-induced, leading them to refer to the disorder as reactive dissociative psychosis.

Apart from hysterical psychosis, Breukink and his contemporaries also distinguished another psychotic category: degenerative psychosis, which was later to be called disintegration psychosis, or borderline psychosis. This diagnostic category of "degenerative psychosis" has not been used in North America but has been common in certain European countries, such as France and the Netherlands. This type of psychosis was often confused with schizophrenia or atypical forms of manicdepressive psychoses. Although a constitutional factor was thought to be involved, the illness developed in many cases as a reaction to stress. In contrast with hysterical psychosis, consciousness was hardly, if at all, changed (Rümke, 1957). According to Kraus (1968), the most typical characteristic of the degenerative psychoses is that they are atypical psychoses. There are polymorphic symptoms, in particular strong fluctuations in states of mind, strange affective experiences, such as so-called cosmic experiences and ecstatic feelings of happiness, a usually confused line of thought, and sometimes hallucinations and delusions.

In conclusion, there is a growing body of studies indicating that a certain number of patients diagnosed as schizophrenics are highly hypnotizable and could be treated by psychotherapy using hypnosis. Contrary to an old European tradition exemplified in the works of Janet and Breukink, in North America such patients are usually diagnosed as schizophrenics. Following these old experts on hypnosis and dissociation, we emphasize the importance of differentiating these patients from schizophrenics, not only on the basis of hypnotizability alone but also on the basis of the dissociative nature of their symptoms and proximate trauma.

2. Breukink's hypnocathartic method for dealing with traumatic memories or complexes illustrates elements of the modern treatment of trauma-induced disorders;

Breukink's use of the work "catharsis" to denote his approach did not refer to emotional expression but to the mental "cleansing" which, he felt, took place when patients related to the therapist the traumatic experiences underlying their psychotic symptomatology. The emphasis of his approach was on keeping the patient in a calm state of mind while exploring and discussing traumatic memories. The same calmness was suggested when the patient would remember in the waking state what was discovered and discussed while under hypnosis. This is reminiscent of Dr. Andries Hoek's hypnotic treatment in 1851 of Rika van B., in which the patient choose to stay in this calm state during hypnotic recounting (see van der Hart \& van der Velden, 1987). Previously, she had relived traumatic memories with extreme emotional expression in her psychotic state.

Breukink contrasted his approach with Janet's substitution method (Janet, 1889/1973, 1898/1983a, 1919/1976; see also van der Hart, Brown, \& Turco, 1990) and Breuer and Freud's hypnocathartic method (see Breuer \& Freud, 1895/1955). Janet used his substitution method with severely disturbed patients who were unable to assimilate and integrate their traumatic memories. He assisted them in substituting alternative, emotionally inert, or even positive imagery. Breukink considered this method too experimental and therefore dangerous, despite Janet's writings. 
Breukink did not mention Janet's other techniques in the treatment of traumatic memories, such as his neutralization technique which he applied in the case of Irène, a patient who was similar to but more severely ill in regard to traumatic background, symptomatology, and treatment than Breukink's first case described above (Janet, 1904/1983b; see also van der Hart, Boon, \& Van Everdingen, 1990; van der Kolk \& van der Hart, 1991). Janet emphasized the integration of traumatic memories into conscious awareness by enabling the patient to talk about these memories first in the hypnotic state and subsequently in her waking state. However, in this more extreme case, Janet was much less able than Breukink to control the patient's intense emotional experience. Indeed, initially traumatic memories may only be available with associated affect, and the working through of this emotion may be necessary for effective treatment (Spiegel \& Cardeña, 1990).

Breukink criticized Breuer and Freud's method, stating that they encouraged abreaction (i.e., affective expression), which he considered dangerous in psychotic patients as it could provoke a new psychotic delirium. Breukink also disagreed with Breuer and Freud for suggesting amnesia for the trauma, as Freud did in the case of Emmy von N. (Breuer \& Freud, 1895/1955). It is true that in the description of their hypnocathartic technique, Breuer and Freud did propose the abreaction of excessive traumarelated emotion as a major therapeutic factor and that Freud even entertained for a while a safetyvalve theory of emotion (Breuer \& Freud, 1895/1955). However, as Nichols and Zax (1977) and Macmillan (1991) have shown, in actual clinical practice Breuer and Freud did not appear to have stimulated emotional expression and at times even discouraged it (as in the case of Freud's Emmy von N.). Breukink was right, however, in stating that with some patients the young Freud used hypnotic suggestions to eliminate the traumatic memories instead of allowing the patient to retain them in his waking state. In describing the treatment of Emmy von N., Freud remarked, "I extinguished her plastic memory of these scenes, but asked her to imagine them once more. She appeared to try to do this and remained quiet as she did so" (Breuer \& Freud, 1895/1955, p. 57).

Shortly before Breukink's publications, an important discussion took place in the British Journal of Medical Psychology on the value of emotional expression in the hypnotic treatment of World War I combat soldiers' traumatic memories (Brown, 1920/1921a, 1920-1921b; Jung, ,1921-1921; McDougall, 1920-1921; Myers, 1920-1921). Although Breukink did not refer to these publications, which dealt with combat soldiers suffering from so-called war neuroses, they bear directly on the issue of the value or danger of encouraging emotional expression during hypnotic reliving of traumatic memories. Brown thought that emotional expression was essential, whereas the other authors considered it to be of relatively little consequence or unnecessary. They warned that it might be actually harmful and increase symptomatology. McDougall argued that the essential problem is the dissociation of the traumatic memory from the psyche and not the existence of strong affect. From this point of view, the essential problem in therapy is not abreaction but the resolution of the dissociation followed by integration. Jung essentially agreed with McDougall and added that integration depended on the rehearsal of the traumatic experience in the presence of an understanding, sympathetic, and trustworthy therapist.

This and Breukink's recommendation is consistent with a series of contemporary studies on expressed emotions (EE) in the families of schizophrenic and other psychotic patients. It has been clearly demonstrated and cross-validated across cultures (some in London, England, same in Los Angeles) that exposing schizophrenics, for instance in their families, to strong emotional expression $(\mathrm{EE}+)$ leads to clinical deterioration and relapse (Brown, Birley, \& Wing, 1987; Doane, West, Goldstein, Rodnick, \& Jones, 1981; Jones, Rodnick, Goldstein, McPherson, \& 'West, 1977; Lewis, Rodnick, \& Goldstein, 1981; Vaugn \& Leff, 1976, 1981; Vaugn et al.,1982).

In modern behavioural, psychodynamic, and strategic approaches to the treatment of traumatic memories, usually same degree of 
emotional expression is encouraged during the confrontation with these memories. In the behavioural flooding technique strong emotional expression is encouraged. Other behavioural approaches stress the extinction of the traumarelated emotions (see Keane, Fairbank, Caddell, Zimering, \& Bender, 1985). Psychodynamic approaches emphasize the need to do this in the context of integration and emphasize regulation of the emotional experience so that the patient can handle the disavowed affects (see Brown \& Fromm, 1986; Gill \& Brenman, 1959; Lavoie, 1990). The same is done in strategic psychotherapy, as described by van der Hart, Boon, and Van Everdingen (1990). The eliciting of traumatic memories is likely to stimulate associated painful affect, but psychotherapy involves restructuring of these memories, with a restructuring of their content along with an enhanced sense of control over the affective arousal associated with them (Spiegel \& Cardeña, 1990). The crucial issue may well be enhancing the patient's ability to regulate emotional arousal more than the intensity of the emotion mobilized in conjunction with traumatic memories.

In line with Breukink's treatment of traumatized psychotic patients, Defares and Brom (1986) argue that traumatized patients who are psychophysiologically vulnerable (including psychotic patients) should be confronted with their traumatic memories in no other state but one of optimal relaxation. From this point of view, what is essential is the authenticity of the experience of trauma-related emotions, not their intensity (van der Hart, Defares, \& Mittendorf, 1991). In facilitating such integration in traumatized psychotic patients, clinicians do well to take heed of Breukink's advice to emphasize a state of calmness in the patient and to be supportive when doing this.

\section{CONCLUSION}

One of the recent developments in the field of hypnosis is the increasing emphasis on the hypnotic treatment of various farms of posttraumatic stress. Our tribute to Breukink's pioneering work with highly hypnotizable, usually traumatized, psychotic patients may perhaps serve as a stimulus to use high hypnotizability in psychotic patients as an indication for hypnotherapy and to identify and treat traumatic memories using hypnotic techniques. Breukink's treatment approach was in harmony with the views of Janet, McDougall, Myers, and Jung. Modern theoretical approaches to dissociation and to the integration of traumatic memories also have much in common with these views. As Janet (1907/1965) pointed out before, it is now recognized that not only the cognitive and affective elements of a traumatic experience must be integrated but all other aspects, such as the physical sensations experienced during the trauma as well (Braun, 1988a, 1988b). In addition, current approaches emphasize the introduction of dissociated memories into full consciousness, using material elicited in hypnosis as part of psychotherapy out of hypnosis. Hypnosis can be used to elicit emotionally charged memories and to control the somatic response to them while allowing the reexperiencing of strong but warded-off affect. If spontaneous dissociation is useful in managing traumatic experiences, dissociative processes can be used in psychotherapy with techniques such as hypnosis to manage memories with their associated affect and arousal. Simple abreaction of such memories without cognitive integration and enhanced control over them can reinforce trauma. Controlled eliciting of such memories can facilitate working through. As Breukink showed 60 years ago, these considerations are especially important in psychotic patients, whose defences are more fragile. His observation of the diagnostic and therapeutic relevance of hypnosis to dissociative and certain psychotic disorders has stood the test of time. 


\section{References}

Bernstein, E. M., \& Putnam, F. W. (1986). Development, reliability, and validity of a dissociation scale. Journal of Nervous and Mental Disease, 174,727-735.

BleuIer, E. (1911). Dementia praecox oderGruppe der Schizophrenien. In G. Aschaffenbury (Ed.), Handbuch der Psychiatrie, specielIer teil 4 Abt. I. Vienna: F. Deuticke.,

Bleuler, E. (1950). Dementia praecox or the group of schizophrenias. Madison, WI: International Universities Press.

Bleuler, M. (1978). Schizophrenic disorders: Long term patient and family studies. New Haven, CT: Yale University Press.

Bleuler, M. (1983). Discussion. British Journal of Psychiatry, 143, 78-79.

Boon, S., \& Draijer, N. (in press). Multiple personality disorder in the Netherlands: A clinical . investigation of 71 patients. American Journal of Psychiatry.

Braun, B. G. (1988a). The BASK (Behavior, Affect, Sensation, Knowledge) model of dissociation. Dissociation, $1(1), 4-23$.

Braun, B. G. (1988b). The BASK model of dissociation: Clinical applications. Dissociation,1 (2), 16-24.

Breuer, J., \& Freud, S. (1955). Studies in hysteria: The standard edition of the complete psychological works of Sigmund Freud, Vol. 2 G. Strachey, Ed. \& Trans.) London: Hogarth. (Original work published 1895)

Breukink, H. (1923a). Over behandeling van sommige psychosen door middel van een bijzonderen vorm der kathartisch-hypnotische methode [On treatment of certain psychoses by means of a special form of the cathartichypnotic method]. Nederlands Tijdschrift voor Geneeskunde [Dutch Journal of Medicine], 67, 1321-1328.

Breukink, H. (1923b). Nieuwere geneeskundige ervaringen over hypnose bij geesteszieken [Newer medical experiences regarding hypnosis with the mentally ill]. Nederlands Tijdschrift voor Geneeskunde, 67, 923-924.

Breukink, H. (1924). Nadere mededeelingen over de hypnotische behandeling van sommige geesteszieken [Further particulars about the hypnotic treatment of certain mentally ill]. Nederlands Tijdschrift voor Geneeskunde, 68,911-918.

Breukink, H. (1925a). Nadere mededeelingen over de behandeling door hypnose bij zenuw- en geesteszieken [Further particulars about treatment by hypnosis of nervous and mentally ill]. Nederlands Tijdschrift voor Geneeskunde, 69, 1877-1887.

Breukink, H. (1925b). Een geval van aangeboren lues en manisch-depressieve psychose [A case of congenital lues and manie depressive psychosis]. Nederlands Tijdschrift voor Geneeskunde, 69, 1003-1006.

Breukink, H. (1925c). De behandeling der neuroses door middel van een bijzondere vorm der kathartische hypnotische methode [The treatment of neuroses with a special form of the cathartic hypnotic method]. Nederlands Tijdschrift voor Geneeskunde, 69, 2065.

Breukink, H. (1926). Psycheasthenische gedruktheid of melancholie? [Psychasthenie depression or melancholia?]. Nederlands Tijdschrift voor Geneeskunde, 70,8-12.

Brown, O., \& Fromm, E. (1986). Hypnotherapy and hypnoanalysis. Hillsdale, NJ: Lawrence Erlbaum.

Brown, G. W., Birley, J.T.L, \& Wing, J. K. (1970). Influence of family life on the course of schizophrenic disorders: A replication. British Journal of Psychiatry, 121, 241-258.

Brown, W. (1920/1921a). The revival of emotional memories and its therapeutic value: 1. British Journal of Medical Psycholog, 1, 16-19.

Brown, W. (1920/1921b). The revival of emotional memories and its therapeutic value: 5. British Journal of Medical Psychology, 1,30-33.

Carpenter, W. T, Bartko, J. J., Strauss, J. S., \& Hawk, A. B. (1978). Signs and symptoms as predictors of outcome: A report from the International Pilot Study of Schizophrenia. American Journal of Psychiatry, 135, 940-945.

Carpenter, W. T, \& Strauss, J. S. (1977). Prediction of outcome in schizophrenia. Archives of General Psychiatry, 34, 159-163.

Ciompi, L. (1980). Catamnestic long-term study on the course of life and aging of schizophrenics. Schizophrenia Bulletin; 6 606-618

Copeland, C. L, \& Kitching, E. A (1937). Hypnosis in mental hospital practice. Journal of Mental Science, 83, 316329.

Defares, P. R, \& Brom, D. (1986). De behandeling van het stress-response-syndrome [Treatment of the stress response syndrome]. In A. P. Cassee et al. (Eds.), Psychotherapie de maat genomen [Measuring psychotherapy] (pp. 136-162). Deventer: Van Loghum Slaterus.

Doane, J. A., West, K. lo, Goldstein, M. J., Rodnick, E H., \& Jones, S. (1981). Parental communication deviance and affective style: Predictors of subsequent schizophrenia spectrum disorders in vulnerable adolescents. Archives of Ge11(_ral Psychiatry, 38, 679-685.

Fink, 0., \& Golinkoff, M. (1990). MPD, borderline personality disorder and schizophrenia: A comparative study of 
clinical features. Dissociation, 3,127-134.

Frank, J. D. (1973). Persuasion and healing: A comparative study of psychotherapy (rev. ed.). Baltimore: Johns Hopkins University Press.

Gill, M. M., \& Brenman, M. (1959). Hypnosis and related states: Psychoanalytic studies in regression. New York: International Universities Press.

Gravestein, V. (1928). In memoriam: Dr. H. Breukink. Geneeskundig Tijdschrift der Rijksverzekeringsbank [Medical Journal of the State Insurance BankJ,13(7), 193-194.

Harding, V. M., \& Brooks, G. W. (1984). Life assessment of a cohort of chronic schizophrenics discharged twenty years ago. In S. Mednick, M. Hanvay, \& K. Finello (Eds.), The handbook of longitudinal research, Vol. 2. New York: Praeger.

Harding, V. M., Brooks, G. W., Ashikaga, T, Strauss, J. S., \& Breier, A. (1987). The Vermont longitudinal study of persons with severe mental illness: 1. Methodology, study sample and overall status 32 years ago. American Journal of Psychiatry, 144,718-726.

Hilgard, E. R. (1965). Hypnotic susceptibility. New York: Harcourt, Brace \& World. Hirsch, S. J., \& Hollender, M. H. (1964). Hysterical psychosis: Clarification of a concept. American Journal of Psychiatry, 125,81-87.

Huber, G., \& Gross, H. (1980). Longitudinal studies of schizophrenic patients. Schizophrenia Bulletin, 6, 592-603.

Janet, P. (1965). The major symptoms of hysteria. New York: Hafner. (Original work published 1907)

Janet, P. (1973). L'Automatisme psychologique [Psychologicaf automatism]. Paris: Société Pierre Janet. (Original werk published 1889)

Janet, P. (1976). Les médications psychologiques, [Psychological healing], 2 vols. New York: Arno Press. (Original werk published 1919)

Janet, P. (1983a). Le traitement psychologique de l'hystérie [Psychological treatment of hysteria]. In P. Janet, l'Etat mental des hystériques [The mental state of hystericaIs] (pp. 619 - 688). Marseille: Lafitte Reprint. (Original werk published 1898)

Janet, P. (1983b). L'Amnésie et la dissociation des souvenirs par l'émotion [Amnesia and the dissociation of memories through affect]. In P. Janet, l'Etat mental des hystériques [The mental state of hystericals] (pp. 506544). Marseille: Lafitte Reprints. (Original work published 1904)

Janet, P. (1983c). L'Etat mental des hystériques [The mental state of hysterics]. Marseille: Lafitte Reprints. (Original werk published 1911).

Janet, P. (1990). Un cas de possession et l'excorcisme moderne [A case of possession and modern exorcism]. In P. Janet, Névroses et idées fixes [Neuroses and fixed ideas], Vol. 1 (pp. 375-406). Paris: Société Pierre Janet. (Original work published 1894-1895)

Jones, J. E, Rodnick, E. H., Goldstein, M. J., McPherson, R. S., \& West, K. lo (1977). Parental transaction style deviance as a possible risk for schizophrenia. Journal of Abnormal Psychology, 90,448-457.

Jung, C. (1921-1922). The question of the therapeutic value of "abreaction." British Journal of Medical Psychology, 2, 13-22.

Keane, T. M., Fairbank, J. A, Caddell, J. M., Zimering, R. T, \& Bender, M. E. (1985). A behavioral approach to assessing and treating post-traumatic stress disorder in Vietnam veterans. In C. Figley (Ed.), Trauma and its wake (pp. 257-294). New York: Brunner / Mazel.

Kluft, R. P. (1987). First rank symptoms as a diagnostic due to multiple personality disorder. American Journal of psychiatry, 144,293-298.

Kraus, G. (1968). Leerboek der psychiatrie [Textbook of psychiatry] (4th ed.). Leiden: H.. E. Stenfert Kroese.

Lavoie, G. (1990). Clinical hypnosis: A psychodynamic approach. In M. lo Fass \& D. Brown (Eds.), Creative mastery in hypnosis and hypnoanalysis: A festschrift for Erika Fromm (pp. 77 105). Hillsdale, NJ; Lawrence Erlbaum.

Lavoie, G., \& Elie, R. (1985). The clinical relevance of hypnotizability in psychosis: With reference to thinking processes and sample variances. In D. Waxman, P. Misra, M. Gibson, \&M. A. Basker (Eds.), Modern trends in hypnosis (pp. 41-66). NewYork: Plenum.

Lavoie, G., Michaud, M., Elie, R.,\& Amar, V. (1987). Hypnotizability as a prognostic index in schizophrenia: 2. The functional relationship between increasing mastery over autistic thinking disorders and improvement in hypnotic response over a 10-17 year period (Abstract) International Journal of Clinical and Experimental Hypnosis, 35,179 .

Lavoie, G., \& Sabourin, M. (1980). Hypnosis and schizophrenia: A review of experimental and clinical studies. In G. D. Burrows \& L. Dennerstein (Eds.), Handbook $f$ Hypnosis and psychosomatic medicine (pp 377-420). Amsterdam \& New York: Elsevier /North-Holland Biomedical Press.

Lewis, J. M., Rodnick, E. H., \& Goldstein, J. M. (1981). Intrafamilial interactive behavior, parental communication 
deviance and risk for schizophrenia. Journal of Abnormal Psychology, 90,448-457.

Loewenstein, R. J. (1991). An office mental status examination for complex chronic dissociative symptoms and multiple personality disorder. Psychiatric Clinics of North America, 14(3),567-604.

Macmillan, M. (1991). Freud evaluated: The completed arc. Amsterdam: North-Holland. Mallett, B. L., \& Gold, S. (1964). A pseudo-schizophrenic hysterical syndrome. British Journal of Psychiatry, 37, 59-70.

McDougall, W. (1920-1921). The revival of emotional memories and its therapeutic value (3). British Journal of Medical Psychology, 1,23-29.

Michaud, M., Lavoie, G., Elie, E., \& Amar, V. (1987). Hypnotizability as a prognostic index in schizophrenia: 1. Prediction of personality improvement and discharge rate over a 10-17 year period (Abstract). International Journal of Clinical and Experimental Hypnosis, 35, 179.

Moreau de Tours, J. J. (1869). Traité pratique de la folie névropathique (vulgo hystérique) [Practical treatise of the neuropathie psychosis (vulgo hysterical). Paris: Baillière.

Murray-Jobsis, J. (1991). An exploratory study of hypnotic capacity of schizophrenic and borderline patients in a clinical setting. American Journal of Clinical Hypnosis, 33(3), 150-160.

Myers, C. S. (1920-1921). The revival of emotional memories and its therapeutic value (2). British Journal of Medical Psychology, 1, 20-22.

Nichols, M., \& Zax, M. (1977). Catharsis in psychotherapy. New York: Gardner. Pettinati, H. M. (1982). Measuring hypnotizability in psychotic patients. International Journal of Clinical and Experimental Hypnosis, 30(4),404416.

Pettinati, H. M., Kogan, L. G., Evans, F. J., Wade, J. H., Home, R. lo, \& Staats, J. M. (1990). Hypnotizability of psychiatrie inpatients according to two different scales. American Journal of Psychiatry, 147,69-75.

Putnam, F. W., Gumff, J. J., Silberman, E. K, Barban, lo, \& Post, R. M. (1986). The clinical phenomenology of multiple personality disorder. Journal of Clinical Psychiatry, 47, 285-293.

Puységur, AM.J. (1816). Les fous, les maniaques et les frénétîues ne seraient-ils qlle des somnambules désordonnés? Ou journal du traitement magnétique du jeune Hébert [Would not the insane, madmen, maniacs, and raving lunaties be disorderly somnambulists? Or the diary of the magnetic treatment of yaung Hébert]. Paris: Dentu.

Ross, C. A. (1989). Multiple personality disorder: Diagnosis, clinical features and treatment. New York: Wiley..

Ross, C. A., Norton, G. R, \& Wozney, K. (1989). Multiple personality disorder: An analysis of 236 cases. Canadian Journal of Psychiatry, 34, 413-418.

Rümke, H. C. (1957). Psychiatrie (2 vols.). Amsterdam: Scheltema \& Holkema.

ScagnelIi, J. (1976). Hypnotherapy with psychotic and borderline patients: The use of trance by patient and therapist. American Journal of Clinical Hypnosis, 25(1), 33-45.

Scagnelli-Jobsis, J. (1982). Hypnosis with psychotic patients: A review of the literature and presentation of a theoretical framework. American Journal of Clinical Hypnosis, 25(1), 33-45.

Spiegel, D. (1988). Hypnosis. In J. A. Talbott, R E Hales, \& S. C. Yudofsky (Eds.), American Psychiatric Press textbook of psychiatry (pp. 217-226). Washington, DC: American Psychiatric Press.

Spiegel, D. (1990). Hypnosis, dissociation, and trauma: Hidden and overt observers. In J.L. Singer (Ed.), Repression and dissociation: Implications for personality theory, psychopathology, and health (pp. 121-142). Chicago: University of Chicago Press.

Spiegel, 0., \& Cardeña, E. (1990). New uses in hypnosis in the treatment of PTSD. Journal of Clinical Psychiatry, 51 (10, SuppI.), 39-43.

Spiegel, 0., Detrick, D., \& Frischholz, E. J. (1982). Hypnotizability and psychopathology. American Journal of Psychiatry, 139, 777-781.

Spiegel, 0., \& Fink, R (1979). Hysterical psychosis and hypnotizability. American Journal of Psychiatry, 136,777781.

Spiegel, H (1991). Invited discussion of "An exploratory study of hypnotic capacity of schizophrenic and borderline patients in a clinical setting." American Journal of Clinical Hypnosis, 33(3), 162-164.

Spiegel, H., \& Spiegel, D. (1987). Trance and treatment: Clinical uses of hypnosis. Washington, DC: American Psychiatric Press. (Original work published 1978)

Steinberg, M., Rounsaville, R, \& Cicchetti, D. V. (1990). Structured clinical interview for DSM-III-R dissociative disorders: Preliminary report on a new diagnostic instrument. American Journal of Psychiatry, 142,953-955. .

Steingard, S., \& Frankel, F. H. (1985). Dissociation and psychotic symptoms. American Journal of Psychiatry, 142,953-955.

Van der Hart, 0., Boon, S., \& Van Everdingen, G. R (1990). Writing assignments in the treatment of traumatic memories. In M. L. Fass \& D. Brown (Eds.), Creative mastery in hypnosis and hypnoanalysis: A festschrift for 
Erika Fromm (pp. 231-253). Hillsdale, NJ: Lawrence Erlbaum.

Van der Hart, a., Brown, P., \& Turco, R N. (1990). Hypnotherapy for traumatic grief: Janetian and modern approaches integrated. American Journal of Clinical Hypnosis, 32(4), 263-271.

Van der Hart, O. Brown, P., \& van der Kolk, B. A. (1989). Pierre Janet's treatment of posttraumatic stress. Journal of Traumatic Stress, 2, 379-396.

Van der Hart, O., Defares, P. R, \& Mittendorff, C. (1991). Trauma-behandeling en de persoon van de therapeut [Trauma treatment and the person of the therapist]. In O. van der Hart (Ed.), Trauma, dissociatie en hypnose [Trauma, dissociation and hypnosis] (pp. 349362). Amsterdam: Swets \& ZeitIinger.

Van der Hart, a., \& van der Velden, K. (1987). The hypnotherapy of Dr. Andries Hoek: Uncovering hypnotherapy before Janet, Breuer, and Freud, American Journal of Clinical Hypnosis, 29(4), 264-271.

Van der Hart, a., Witztum, E, \& Friedman, B. (1993). From hysterical psychosis to reactive dissociative psychosis. Journal of Traumatic Stress, 6(1),43-64. .

Van der Kolk, R A, \& van der Hart, 0. (1991). The intrusive past: The flexibility of memory and the engraving of trauma. American Imago, 48(4), 425-454.

VanderIinden, J., van Dyck, R, Vandereycken, W., \& Vertommen, H. (1991). Dissociative experiences in the general population in the Netherlands and Belgium. Dissociation, 4(4),180-184.

Vaugn, C. E., \& Leef, J. P. (1976). The influence of family and soáal factors in the course of psychiatric illness. British Journal of Psychiatry, 129, 125-137.

Vaugn, C. E., \& Leef, J. P. (1981). Patterns of emotional response in relatives of schizophrenic patients. Schizophrenia Bulletin, 7,43-44.

Vaugn, C. E.,Snyder, K. S., Freeman, w.,Jones, S., Falloon, I.R.H., \& Liebennan, R. P. (1982). Family factors in schizophrenic relapse: A replication. Schizophrenia Bulletin, 8, 425-426.

Viëtor, W.P.J.(I964). Hypnosis in the Netherlands: A historical review of the Dutch literature about 1900, Part 2: Bollaan, Stigter and Breukink. British Journal of Medical Hypnosis, 15(6),25-27.

Weitzenhoffer, A. M., \& Hilgard, E. R. (1959). Stanford Hypnotic Susceptibility Scale, Forms A and B. Palo Alto, CA: Consulting Psychologists Press.

Weitzenhoffer, A. M., \& Hilgard, E. R. (1962). Stanford Hypnotic Susceptibility Scale, Form C Palo Alto, CA: Consulting Psychologists Press.

Wetterstrand, O. G. (1892). Ueber den künstlich verlängerten Schlaf, besonders bei der Behandlung der Hysterie [About the artificially extended sleep, in particular in the treatment of hysterial. Zeitschrift für Hypnotismus, 1, 17-23.

Witzturn, E., Buchbinder, J.T., \& van der Hart, O. (1990). Summoning a punishing angel: Treatment of a depressed patient with dissociative features. Bulletin of the Menniger Clinic, 54 (4), 524-537. 


\section{Hypnotische Bewertung und Behandlung voo Trauma-induzierten Psychosen: Die frühe Psychotherapie von H. Breukink und moderne Anschauungen}

Abstrakt: Die Rolle der Hypnotisierbarkeitsbewertung in der differentialen Diagnose bei psychotisch en Patienten ist immer noch nicht geklärt. In dieser Abhandlung wird das bahnbrechen Werk des holländischen Psychiaters, H. Breukink (1860-1928), während der 1920er als früher Beweis gebraucht, dass hypnotische Fähigkeit klinisch hilfreich sein kann in der Differenzierung der stark hypnotisierbaren, psychotischen Patienten mit dissoziativer Symptomatologie von schizophrenen. Weiterhin besteht eine lange Tradition des Gebrauchs der hypnotischen Fähigkeit in der Behandlung solcher dissoziativen Psychosen. Das Verfahren, in dem Breukink Hypnose für diagnostische, prognostische und Behandlungszwecke benutzte, wird zusammengefasst und im Hinblick auf hergebrachte wie gegenwärtige Ansichten diskutiert. Er glaubte, dass eine hysterische Psychose Trauma-induziert und gewisslich heilbar war und dass Psychotherapie mit Anwendung von Hypnose eine vorgezogene Behandlungsweise darstellte. Hypnose wurde als symptomorientierte Therapie gebraucht, als ein bequemer und unterstützender Geisteszustand und für das Entdecken und Integrieren der traumatischen Erinnerungen. Für den letzteren Zweck legte Breukink das Hauptgewicht auf einen ruhigen Geisteszustand, sowohl in Hypnose wie im Wachzustend, dadurch gefühlsmässige Ausdrücke entmutigend, die er als gefährlich bei psychotischen Patienten betrachtete. In der Diskussion wied besondere Aufmerksamkeit der Rolle und den Gefahren des Ausdrucks voo traumabezogenen Gefühlen geschenkt.

\section{L'hypnose dans I'évaluation et le traitement de psychoses provoquées par traumatismes: la psychothérapie pionnière de $\mathrm{H}$. Breukink et vision plus moderne}

Résumé: Le rôle de l'hypnotisabilité dans le diagnostic différentiel de patients psychotiques est toujours problématique. Dans cet artic1e, les travaux pionniers du psychiatre hollandais H. Breukink (1860-1928), durant les années 20, servent de base pour documenter l'utilité clinique de l'hypnose afin de différentier les patients psychotiques fortement hypnotisables avec une symptómatologie dissociative, des patients schizophrènes. De plus, il existe une longue tradition quant à l'utilisation de la capacité hypnotique dans le traitement des psychoses dissociatives. La façon dont Breukink utilisait l'hypnose pour des fins de diagnostic, de pronostic et de traitement est résumée et discutée à la lumière des conceptions anciennes et modernes. Breukink avançait l'idée que la psychose hystérique était induite par traumatisme, certainement guérissable, et que la psychothérapie utilisant l'hypnose constituait un traitement de choix. L'hypnose était utilisée dans un cadre de thérapie orientée sur les symptómes, comme un état mental confortable et sécurisant et aussi pour faire émerger les souvenirs traumatiques et les intégrer. Pour ce dernier usage, Breukink recommande l'utilisation d'un état de calme mental, autant en hypnose qu'en état d'éveil, et décourage l'expression émotive qu'il considère comme dangereuses chez les patients psychotiques. Dans la discussion, une attention spéciale est accordée au róle et dangers de l'expression des émotions reliées au traumatisme.

Evaluacion y tratamiento hipnotico de psicosis traumaticas:

\section{la psicoterapia primitiva de $\mathbf{H}$. Breukink y una vision contemporanea}

Resumen: EI rol de la evaluacion de la hipnotizabilidad en el diagnóstico diferencial de pacientes psicóticos no ha sido resuel to todavía. En este estudio, el trabajo pionero realizado durante los aiios 1920 por el psiquiatra holandés H. Breukink (1860-1928) es utilizado coma una evidencia temprana de que la capacidad hipnótica es clfnicamente util para diferenciar pacientes psicóticos con sintomatologia disociativa y aItamente hipnotizables de los pacientes esquizofrénicos. Además existe una larga tradición en el empleo de la capacidad hipnótica en el tratamiento de éstas psicosis disociativas. Las maneras en que Breukink utilizó la hipnosis para diagnóstico, pronóstico y tratamiento son repertoriadas y discutidas a las luz de los puntos de vista contemporáneos y de la época. Breukink pensaba que la psicosis histérica era inducida traumáticamente, ciertamente curable y que la psicoterapia que utilizaba la hipnosis era el tratamiento de elección. Se usaba la hipnosis coma una terapia sintomática, coma una condición para una mejorfa general y para descubrir e integrar recuerdos traumáticos. Para es te ultimo propósito Breukink enfatizaba un estado de calma mentat en estado hipnótico y de vigilia, desalentando la expresión emocional considerada peligrosa para los pacientes psicóticos. Se acuerda especial atención en la discusión al rol y peligros de la expresión de emociones relacionadas con la traumático. 